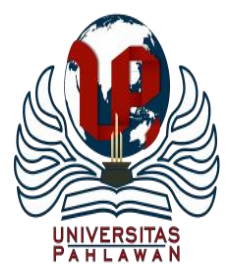

Edukatif : Jurnal Ilmu Pendidikan Volume 3 Nomor 2 Tahun 2021 Halm 514 - 522 EDUKATIF: JURNAL ILMU PENDIDIKAN

Research \& Learning in Education

https://edukatif.org/index.php/edukatif/index

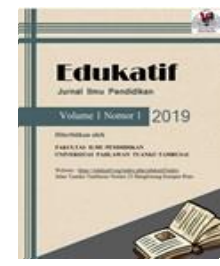

\title{
Membangun Karakter Generasi Muda Melalui Implementasi Nilai-Nilai Pancasila Di Tengah Arus Globalisasi
}

\author{
Rani Fitriani $^{1 凶}$, Dinie Anggraeni Dewi \\ Universitas Pendidikan Indonesia ${ }^{1,2}$

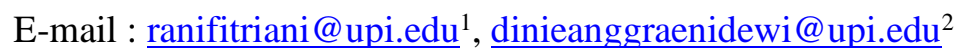

\begin{abstract}
Abstrak
Pancasila merupakan ideologi bangsa Indonesia yang di jadikan pedomanan hidup dalam berbangsa dan bernegara, pesatnya arus globalisasi menunjukan pengikisan karakter masyarakat di Desa Majasetra Kecamatan Majalaya. Hal ini dapat ditunjukan dengan maraknya kekerasan di lingkungan tersebut, selain itu kasus pembunuhan sopir delman yang tragis menunjukan bagaimana karakter di Desa Majasetra belum sepenuhnya mencerminkan karakter bangsa Indonesia yang sesuai dengan nilai-nilai Pancasila. Metode yang digunakan dalam penelitian berupa studi kasus dimana peneliti melakukan pengamatan di Desa Majasetra peneliti menyelidiki secara cermat suatu peristiwa, aktivitas, dan proses sekelompok individu yang dibatasi oleh waktu dan peristiwa. Dari penelitian yang sudah dilakukan Penjabaran Nilai-nilai yang ada pada setiap sila Pancasila dapat dijadikan pondasi dalam membangun karakter masyarakat di Desa Majasetra agar dapat menunjukan karakter warga negara yang baik. Nilai-nilai Pancasila itu antara lain nilai religius, nilai kejujuran, nilai toleran, nilai disiplin, nilai mandiri, nilai demokratis, rasa ingin tahu, nilai semangat kebangsaan, nilai cinta damai, nilai peduli terhadap lingkungan, dan nilai peduli sosial. Penjabaran dari nilai-nilai pancasila tersebut dapat ditumbuhkan dan ditanamkan pada masyarakat Majasetra untuk membangun karakter masyarakat Majasetra yang sesuai dengan karakter warga negara Indonesia sehingga dapat meminimalisir penyimpangan-penyimpangan akibat yang diakibatkan dengan adanya perubahan yang di bawa arus globalisasi saat ini.
\end{abstract}

Kata Kunci: Pancasila, Karakter bangsa, Globalisasi

\begin{abstract}
Pancasila is the ideology of Indonesian people which is used as a guide to live in the nation and state. The rapid flow of globalization shows the degradation of the character of the people in Majasetra Village, Majalaya District. This can be shown by the violence in that happens a lot in the neighborhood, besides the tragic case of the murder of a delman driver, it shows how the character in Majasetra Village does not fully reflect the character of Indonesian people which is in accordance with the values of Pancasila. The method used in the research is a case study where the researcher did observations in the Majasetra Village, the researcher carefully investigated the events, activities, and the process of a group of people in a limited time and condition. From the research that has been done, the description of the values that exist in each Pancasila principle can be used as a foundation in building the character of the people in Majasetra Village in order to show the character of good citizens. The values of Pancasila include religious values, honesty values, tolerant values, disciplinary values, independent values, democratic values, curiosity, national spirit values, peace-loving values, caring for the environment, and social care values. The description of these Pancasila values can be cultivated and instilled in the Majasetra community to form the character of the Majasetra people in accordance with the character of Indonesian principle to minimize immorality caused by changes as the effect of globalization.
\end{abstract}

Keywords: Pancasila, National Character, Globalization

Copyright (c) 2021 Rani Fitriani, Dinie Anggraeni Dewi

$\triangle$ Corresponding author

Email : ranifitriani@upi.edu

DOI $\quad$ : https://doi.org/10.31004/edukatif.v3i2.367

ISSN 2656-8063 (Media Cetak)

ISSN 2656-8071 (Media Online)

Edukatif : Jurnal Ilmu Pendidikan Vol 3 No 2 Tahun 2021

p-ISSN 2656-8063 e-ISSN 2656-8071 


\section{Membangun Karakter Generasi Muda Melalui Implementasi Nilai-Nilai Pancasila Di Tengah Arus Globalisasi - Rani Fitriani, Dinie Anggraeni Dewi \\ DOI: https://doi.org/10.31004/edukatif.v3i2.367}

\section{PENDAHULUAN}

Pancasila merupakan ideologi bangsa Indonesia. Sebagai dasar negara, Pancasila dijadikan landasan dalam berkehidupan. Untuk menjadi warga negara yang baik Good Citizen maka nilai-nilai Pancasila perlu mendasari dalam setiap pribadi, hal ini membuktikan peran penting Pancasila sebagai landasan atau pandangan hidup tentang bagaimana seharusnya menjadi warga negara yang baik Good citizen. Nilai-nilai yang terkandung dalam Pancasila akan mengajarkan cara berpikir dan bertindak sesuai dengan ideologi negara seharusnya.

Dewasa ini, arus globalisasi yang semakin pesat membawa tantangan tersendiri terhadap eksistensi Pancasila, berbagai aspek kehidupan merasakan dampaknya, dampak negatif yang dibawa tidak dapat dihindari salah satunya adalah adanya pengaruh dari budaya luar yang mempengaruhi nilai-nilai karakter yang tidak sesuai dengan nilai-nilai Pancasila seperti munculnya gaya hidup konsumtif, sifat hedonisme, sikap individualisme, gejala westernisasi, semakin memudarnya semangat gotong royong dan hilangnya nilai keagamaan dalam kehidupan. Hal ini menjadi sesuatu yang perlu diperhatikan, jika dibiarkan begitu saja, nilai-nilai Pancasila seakan tidak tertanam pada masyarakat Indonesia. Banyak masyarakat yang tidak tahu betapa pentingnya nilai-nilai Pancasila tersebut karena pengaruh globalisasi.

Berbagai tantangan yang muncul akibat adanya pengaruh globalisasi terhadap keberadaan Pancasila merupakan tantangan dan ancaman yang besar dan tidak bisa dihiraukan begitu saja. Pengaruh negatif yang dibawa globalisasi dengan mudahnya mempengaruhi kehidupan masyarakat Indonesia. Seiring berjalannya waktu hal ini tentu akan mempengaruhi karakter masyarakat yang tidak sesuai dengan karakter bangsa Indonesia dan ini lah yang terjadi dewasa ini "Karakter mengacu kepada serangkaian sikap (attitude), perilaku (behavior), motivasi (motivation), dan keterampilan (skill)"(Gunawan, 2012). di mana karakter ini harus dibangun dan dikembangkan secara sadar hari demi hari melalui sebuah proses yang tidak instan.

Adanya pengaruh globalisasi yang membawa perubahan terhadap karakter masyarakat yang tidak sesuai dengan nilai-nilai Pancasila tersebut dikhawatirkan akan melupakan jati diri bangsa yang menjunjung tinggi nilai-nilai Pancasila sebagai dasar untuk menjadi warga negara yang baik Good Citizen yang merupakan pengaplikasian bangsa Indonesia itu sendiri.

Dewasa ini, nilai-nilai agama dan budaya tidak dijadikan sumber etika dalam berbangsa dan bernegara oleh sebagian masyarakat. Hal ini akhirnya melahirkan penyimpangan-penyimpangan moral berupa ketidakadilan, pelanggaran hukum, pelanggaran hak asasi manusia dan kurangnya pemahaman, penghayatan dan kepercayaan akan keutuhan pada sila Pancasila. Hal ini dapat di lihat di desa Majasetra, dimana masih banyaknya penyimpangan sosial yang terjadi, seperti tawuran, kenakalan remaja, bahkan pembunuhan yang dilakukan kepada seorang supir delma dilansir dalam Kompas.com.

Berdasarkan pernyataan diatas, eksistensi Pancasila dalam kehidupan berbangsa dan bernegara keberadaannya penting. Nilai-nilai yang terkandung pada setiap sila Pancasila merupakan wujud dari karakter bangsa Indonesia sebagai cerminan warga negara yang baik Good Citizen. Dalam hal ini, Pancasila berupaya membangun karakter bangsa Indonesia dalam menghadapi dampak dari arus globalisasi, maka diperlukan implementasi nilai-nilai Pancasila untuk dapat membangun dan menjadi benteng pelindung dalam menumbuhkan kembali karakter bangsa yang luntur akibat adanya pengaruh globalisasi. Oleh karena itu, penelitian ini dilakukan guna menumbukan karakter generasi muda sebagai penerus bangsa yang seharusnya dapat terwujud agar terciptanya karakter-karekter yang dapat membangun dan mewujudkan nilai-nilai yang mencerminkan kehidupan bangsa Indonesia. Nilai-nilai yang membentuk karakter ini tentunya dapat menjadi benteng pelindung dari pesatnya arus globalisasi yang terjadi saat ini. 
DOI: https://doi.org/10.31004/edukatif.v3i2.367

\section{METODE PENELITIAN}

Pendekatan yang digunakan dalam penelitian ini adalah pendekatan kualitatif yaitu suatu penelitian yang menghasilkan suatu data deskriptif berupa ucapan, tulisan dan perilaku yang dapat diamati secara langsung. Pendekatan ini dilakukan guna menghimpun informasi terkait dengan karakter masyarakat di Desa Majasetra Kecamatan Majalaya Kabupaten Bandung. Berdasarkan tema yang di bahas penelitian ini digolongkan ke dalam jenis penelitian studi kasus yang dilakukan di Desa Majasetra Kecamatan Majalaya Kabupaten Bandung. Peneliti menggunakan penelitian ini karena keadaan lokasi yang mudah di jangkau juga dapat memperoleh data-data yang sesuai dan dapat menjawab persoalan yang terjadi sesuai dengan pokok permasalahan. Adapun yang menjadi studi kasus dalam penelitian ini mengenai pembangunan karakter di Desa Majasetra.

Sesuai dengan jenis penelitian yang bersifat kualitatif kehadiran peneliti di lapangan sangat dan diperlukan secara optimal, oleh karena itu dalam penelitian ini peneliti terjun langsung ke lapangan untuk mengamati dan mengumpulkan data yang di butuhkankan. Adapun sumber data yang diperoleh dari pengamatan yaitu perilaku masyarakat di Desa Majasetra yang diamati atau di wawancarai. Dalam memperoleh data peneliti melakukan observasi atau pengamatan secara langsung untuk melihat dari dekat bagaimana karakter dibangun pada masyarakat Majasetra, selain itu peneliti melalukan wawancara dengan melibatkan masyarakat Majasetra. Waktu yang diperlukan dalam melakukan penelitian berangsur selama satu pekan.

Sebelum melakukan penelitian, peneliti menyerahkan permohonan penelitian kepada masyarakat Majasetra hal ini dimaksud agar dalam penelitian dapat berlangsung dengan baik dan dapat pula mendapat tanggapan yang baik dari dimulainya penelitian sampai akhir penelitian selesai hal ini juga dilakukan agar tetap mempertahankan sikap terbuka dan kejujuran.

\section{HASIL DAN PEMBAHASAN PENELITIAN}

Berdasarkan penelitian yang dilakukan bahwa keadaan nilai-nilai Pancasila di perkampungan Majasetra kecamatan Majalaya belum terimplementasikan sepenuhnya, hal ini dikarenakan masih maraknya penyimpangan-penyimpangan moral di tengah masyarakat seperti kekerasan terhadap orang lain, tawuran, pergaulan bebas seperti minum-minuman keras, bahkan pembunuhan marak terjadi di Kawasan tersebut. Hingga pada akhir Desember 2020 terjadi kasus pembunuhan seorang sopir delman oleh temannya dengan motif sakit hati. Pelaku sendiri, ketika melakukan tindakan tersebut di bawah pengaruh minuman keras. Hal ini menunjukan bagaimana nilai-nilai Pancasila belum tercermin sepenuhnya.

Pemahaman nilai-nilai Pancasila seolah tiada. Selain itu, setelah melakukan beberapa survei pada masyarakat di lingkungan Majahtera khususnya generasi muda mengenai butir-butir sila yang terdapat pada Pancasila hasil yang didapat beragam, kebanyakan masyarakat di lingkungan tersebut bahkan tidak mengetahui betul butir pancasila, sungguh sangat disayangkan. Padahal, Pancasila merupakan salah satu ciri yang menunjukan pribadi bangsa Indonesia, melihat keadaan ini tentunya menjadi sebuah tantangan apalagi, penyimpangan moral ini tidak luput dipengaruhi arus globalisasi yang pesat. Hal ini dapat dilihat dari maraknya generasi muda kalangan usia Sekolah Dasar (SD) yang terlihat memainkan gadget ketimbang bermain aktif di lingkungannya. Usia-usia kanak-kanak di daerah tersebut secara tidak langsung mudah mengakses informasi apa saja, dan yang disayangkan pengawasan orang tua belum berperan secara optimal. 


\section{Membangun Karakter Generasi Muda Melalui Implementasi Nilai-Nilai Pancasila Di Tengah Arus Globalisasi - Rani Fitriani, Dinie Anggraeni Dewi \\ DOI: https://doi.org/10.31004/edukatif.v3i2.367}

Mengimplementasikan nilai-nilai pada Pancasila belum tercermin melihat masyarakatnya sendiri belum mengenal, bahkan mengetahui benar butir yang terdapat pada Pancasila. Untuk itu, masyarakat Majasetra perlu diberikan pembudayaan mengenai Pancasila. Dengan pembudayaan Pancasila tersebut akan membantu masyarakat untuk dapat membangun karakter generasi muda di desa Majasetra yang mencerminkan karakter bangsa Indonesia sebagai good citizen.

Secara etimologis Pancasila berasal dari bahasa sansekerta yaitu Panca dan Sila. Panca berarti lima dan Sila berarti, batu, sendi, alas atau dasar, jadi Pancasila berarti berbatu sendi lima atau memiliki lima dasar. Pancasila sebagai dasar negara merupakan landasan bagi penyelenggara negara dan pelaksanaan sistem pemerintahan yang memiliki kedudukan tinggi, sumber bagi segala sumber hukum yang ada di Indonesia. Nilai-nilai pada Pancasila dijadikan pandangan hidup bangsa Indonesia. Oleh karena itu, segala aturan yang ada harus berdasarkan Pancasila.

Pancasila menurut (Lasiyo et al., 2019) merupakan dasar negara yang sudah seharusnya dipelajari, didalami, dikembangkan serta diimplementasikan dalam kehidupan sehari-hari dalam setiap aspek bermasyarakat, berbangsa dan bernegara yang kemudian pendalaman dan penghayatan Pancasila itu disesuaikan dengan kemampuan masing-masing individu dengan memperhatikan potensi yang ada pada diri individu. Menurut (Kaelan, 2012) jati diri bangsa Indonesia berasal dari nilai-nilai Pancasila yang merupakan hasil pemikiran dan gagasan bangsa Indonesia tentang kehidupan yang dianggap baik yang memberikan watak, corak, dan ciri masyarakat Indonesia sendiri. Corak dan watak yang dimaksud antara lain sikap bangsa yang religius, menghormati bangsa dan manusia lain, adanya sikap cinta persatuan, gotong royong, musyawarah dan keadilan sosial. Oleh karena itu, bangsa Indonesia hendaknya bisa menyelaraskan nilai-nilai Pancasila sebagai jati diri bangsa.

Hardono Hadi dalam (Winarno, 2020) menyatakan Pancasila sebagai jati diri bangsa mencangkup empat aspek, yaitu Pancasila sebagai kepribadian bangsa Indonesia, Pancasila sebagai identitas bangsa Indonesia, dan Pancasila sebagai keunikan bangsa Indonesia. Pancasila sebagai kepribadian ini lah yang perlu ditanamkan pada diri bangsa Indonesia. Nilai-nilai Pancasila perlu dilibatkan dalam karakter setiap masyarakat Indonesia, sehingga eksistensi Pancasila sebagai identitas negara dapat tercerminkan.

Adapun karakter menurut (Kosim, 2011)berasal dari bahasa Yunani yaitu charassein yang memiliki arti mengukir. Dalam hal ini karakter pada seseorang haruslah dapat diukir, dibentuk dan dikembangkan. Dalam kamus besar bahasa Indonesia karakter diartikan sebagai tabiat, sifat-sifat, kejiwaan, akhlak atau budi pekerti yang membedakan seseorang dengan yang lain. Karakter dapat diartikan sebagai tabiat, watak, akhlak, atau kepribadian seseorang yang terbentuk dari hasil internalisasi yang diyakini dan digunakan sebagai cara berfikir dan berperilaku yang menjadi ciri khas tiap individu untuk hidup dan bekerja sama baik dalam lingkup keluarga, masyarakat, bangsa dan negara. Individu yang berkarakter baik adalah individu yang dapat membuat keputusan dan siap mempertanggungjawabkan akibat dari keputusan yang dibuatnya (Suyatno, 2009:1).

Dewasa ini karakter bangsa Indonesia seolah meluntur banyak terjadi penyimpangan-penyimpangan moral yang tidak sesuai dengan nilai-nilai Pancasila seperti meningkatnya kekerasan, hilangnya nilai kejujuran, perpecahan di mana-mana, kurang pedulinya terhadap orang lain dan lain lain (YALIDA, 2019). Jika dibiarkan begitu saja bangsa Indonesia bisa kehilangan jati dirinya hal ini sejalan dengan yang dikatakan Thomas Lickona (1992) dalam (Eva Imania Eliasa, 2008) bahwa terdapat sepuluh tanda perilaku manusia yang menunjukkan arah kehancuran suatu bangsa yaitu: (1) Meningkatnya kekerasan di kalangan remaja, (2) Ketidakjujuran yang membudaya, (3) Semakin tingginya rasa tidak hormat kepada orang tua, guru, dan figur pemimpin, (4) Pengaruh teman sebaya terhadap tindakan kekerasan, (5) Meningkatnya kecurigaan dan kebencian, (6) Penggunaan bahasa yang buruk, (7) Penurunan etos kerja, (8) Menurunnya rasa tanggung 


\section{Membangun Karakter Generasi Muda Melalui Implementasi Nilai-Nilai Pancasila Di Tengah Arus Globalisasi - Rani Fitriani, Dinie Anggraeni Dewi \\ DOI: https://doi.org/10.31004/edukatif.v3i2.367}

jawab individu dan warga negara, (9) Meningkatnya perilaku merusak diri, (10) Semakin kaburnya pedoman moral. Salah satu penyebab menurunnya karakter bangsa antara lain karena adanya pengaruh globalisasi.

Menurut (Nurhaidah, 2015)globalisasi dapat diartikan sebagai proses masuknya keruang lingkup dunia. Globalisasi memberikan dampak baik itu positif maupun negatif. Globalisasi menyentuh seluruh aspek penting kehidupan. Globalisasi menciptakan berbagai tantangan dan permasalahan baru sehingga nilai-nilai karakter bangsa juga ikut terpengaruhi hal ini banyak menimbulkan penyimpangan-penyimpangan dalam berbagai aspek.Menurut (Rachmah, 2013) Karakter dan budaya suatu bangsa harus dipertahankan sehingga dapat dibedakan antara bangsa yang satu dengan yang lainnya. Untuk mempertahankan eksistensi bangsa Indonesia perlu melakukan pembangunan karakter yang merupakan upaya perwujudan dari nilai-nilai Pancasila. Nilai-nilai Pancasila dapat dijadikan upaya perwujudan nilai-nilai karakter bangsa. Pesatnya arus globalisasi membawa pengaruh kuat terhadap eksistensi Pancasila, oleh karena itu penerapan nilai-nilai Pancasila patut dijadikan landasan dan pedoman dalam berkehidupan berbangsa dan bernegara. upaya pembangunan karakter dengan nilai-nilai Pancasila inilah yang dapat mambangun karakter bangsa sesuai dengan budaya yang ada. Pemahaman yang dalam perlu dilakukan dalam upaya membantu membentuk karakter bangsa.

Pancasila memiliki serangkaian nilai, yaitu ketuhanan, kemanusiaan, persatuan, kerakyatan, dan keadilan. Kelima nilai tersebut merupakan satu kesatuan yang utuh di mana mengacu dalam tujuan yang satu. Nilai-nilai dasar Pancasila seperti ketuhanan, kemanusiaan, persatuan, kerakyatan, dan keadilan yang bersifat universal, objektif, artinya nilai-nilai tersebut dapat dipakai dan diakui oleh negara-negara lain. "Sebagai suatu ideologi bangsa dan Negara Indonesia, maka Pancasila pada hakikatnya bukan hanya merupakan suatu hasil perenungan atau pemikiran seseorang atau kelompok orang sebagaimana ideologi-ideologi lain di dunia, namun Pancasila diangkat dari nilai-nilai adat-istiadat, nilai-nilai kebudayaan serta nilai religius yang terdapat dalam pandangan hidup masyarakat Indonesia"(Asmaroini, 2016).

Dalam implementasi nilai-nilai Pancasila pada masyarakat desa Majasetra terhadap pembangunan karakter tidak selalu berjalan dengan baik. Banyak hambatan-hambatan yang terjadi akibat arus globalisasi yang begitu cepat membawa masyarakat cenderung berorientasi pada nilai- nilai dan budaya luar (Nurhaidah, 2015). Ancaman Krisis karakter akibat arus globalisasi antara lain, munculnya gaya hidup konsumtif dan selalu mengkonsumsi barang -barang dari luar negeri, munculnya sifat hedonisme yaitu kenikmatan pribadi dianggap sebagai suatu nilai hidup tertinggi hal ini yang membuat manusia memaksakan diri untuk mencapai kenikmatan dan kepuasan pribadinya tersebut meskipun harus melanggar norma-norma yang berlaku di masyarakat seperti mabuk-mabukan, foya-foya, dan pergaulan bebas, Adanya sikap individualisme yaitu sikap selalu mementingkan diri sendiri serta memandang orang lain itu tidak ada dan tidak bermakna. Sikap seperti ini dapat menimbulkan ketidakpedulian terhadap orang lain.

Selain itu, munculnya gejala westernisasi atau gaya hidup yang selalu berorientasi kepada budaya barat tanpa diseleksi terlebih dahulu juga dapat mempengaruhi contohnya Seperti meniru model pakaian orang barat yang sebenarnya bertentangan dengan nilai dan norma-norma yang berlaku, misalnya perempuan memakai rok mini dan laki-laki memakai anting. Dampak negative globalisasi juga membuat semakin memudarnya semangat gotong royong, solidaritas, kepedulian, dan kesetiakawanan sosial, semakin lunturnya nilai keagamaan dalam kehidupan bermasyarakat yang mana pengetahuan akan ilmu agama ini sangat penting dan bermanfaat di kalangan remaja, di mana pengetahuan agama akan mengontrol diri para remaja dan menghindari perbuatan yang buruk.

Maraknya penyimpangan yang terjadi pada masyarakat Majasetra menimbulkan pengikisan pada karakter masyarakatnya. Oleh sebab itu, pembudayaan nilai-nilai Pancasila perlu didalami. Pembudayaan sendiri dalam (Ad, 2016) yaitu memelihara dan menjaga nilai-nilai tetap yang dipertahankan dan dilaksanakan 
semestinya. Nilai-nilai yang ada dalam Pancasila perlu dibudayakan untuk dapat diimplementasikan di dalam kehidupan masyarakat. Dalam (Septian, 2020) nilai-nilai Pancasila sendiri mengandung arti sebagai berikut:

\section{Tabel 1}

\section{Nilai-Nilai Sila Pancasila}

\begin{tabular}{|l|l|}
\hline Ketuhanan Yang Maha Esa & $\begin{array}{l}\text { Sila Ketuhanan Yang Maha Esa bermakna bahwa bangsa Indonesia adalah } \\
\text { negara yang percaya terhadap adanya Tuhan dengan itu negara Indonesia } \\
\text { berlandaskan agama. Untuk itu, sudah semestinya kita menanamkan nilai- } \\
\text { nilai kebenaran, kebaikan, kejujuran, dan kemuliaan dalam diri sehingga } \\
\text { moral bangsa mencerminkan sikap percaya dan taqwa terhadap Tuhan } \\
\text { YME. }\end{array}$ \\
\hline $\begin{array}{l}\text { Kemanusiaan Yang Adil dan } \\
\text { Beradab }\end{array}$ & $\begin{array}{l}\text { Pada sila kedua nilai yang terkandung yaitu nilai kemanusian. kemanusian } \\
\text { yang dimaksud adalah manusia yang menjunjung tinggi keadilan dan } \\
\text { martabat yang diwujudkan dalam sikap toleransi }\end{array}$ \\
\hline Persatuan Indonesia & $\begin{array}{l}\text { Nilai pada sila ketiga ini dapat diwujudkan dengan sikap saling } \\
\text { menghargai keberagaman yang ada di Indonesia dengan cara cinta tanah } \\
\text { air, rela berkorban, dan mengutamakan persatuan dan kesatuan bangsa }\end{array}$ \\
\hline $\begin{array}{l}\text { Kerakyatan Yang Dipimpin } \\
\text { Oleh Hikmat Kebijaksanaan } \\
\text { Dalam } \\
\text { Permusyawaratan/Perwakilan }\end{array}$ & $\begin{array}{l}\text { Sila keempat mengandung makna sebagai warga negara kita mempunyai } \\
\text { kedudukan, hak, dan kewajiban yang sama untuk itu musyawarah dalam } \\
\text { mencapai mufakat dan nilai semangat dalam kekeluargaan perlu } \\
\text { ditanamkan dalam mengambil keputusan. }\end{array}$ \\
\hline $\begin{array}{l}\text { Keadilan Sosial Bagi Seluruh } \\
\text { Rakyat Indonesia }\end{array}$ & $\begin{array}{l}\text { Nilai pada sila kelima ini mengandung makna bahwa setiap warga negara } \\
\text { haruslah diperlakukan sama tanpa memandang perbedaan baik agama, ras, } \\
\text { suku dan budaya, miskin atau kaya. Semua warga negara memiliki } \\
\text { kedudukan yang sama dan haruslah diperlakukan seadil mungkin. Nilai- } \\
\text { nilai yang terkandung dapat diwujudkan melalui sikap keadilan dalam } \\
\text { kehidupan, melindungi seluruh bangsa, bersikap adil, memberi } \\
\text { pertolongan, dan mewujudkan kesejahteraan bangsa. }\end{array}$ \\
\hline
\end{tabular}

Untuk itu, pancasila sebagai dasar negara berperan dalam menciptakan manusia yang berkarakter. di tengah arus globalisasi yang pesat banyak karakter-karakter pada masyarakat Majasetra yang terpengaruh akibatnya. Munculnya berbagai penyimpangan-penyimpangan yang menghilangkan karakter masyarakat Majasetra dinilai menjadi permasalahan yang perlu diperhatikan. Menurut (Anggraini et al., 2020) Nilai Pancasila pada dasarnya adalah nilai-nilai yang mendasar di mana nilai- nilai ini dijadikan aturan dan dasar pada norma-norma yang berlaku di Indonesia. Dewasa ini, perlu penegasan akan nilai-nilai Pancasila dalam membangun karakter bangsa.

Nilai-nilai yang terkandung dalam Pancasila akan mengajarkan cara berpikir dan bertindak sesuai dengan ideologi negara (Damanhuri et al., 2016). Banyaknya pengaruh negatif terhadap bangsa Indonesia salah satunya adalah lunturnya nilai-nilai luhur yang melekat dalam suatu negara, dengan banyaknya pengaruh dari budaya luar akibat pesatnya arus globalisasi masyarakat Majasetra tidak bisa memilah dan memilih sehingga nilai-nilai tersebut tidak sesuai dengan nilai-nilai Pancasila sebagai bentuk warga negara yang baik Good Citizen yang merupakan aplikasi karakter dari bangsa Indonesia.

Menurut Kaelan dalam (Winarno, 2020) pancasila dikatakan sebagai filsafat pada hakikatnya merupakan suatu nilai. Nilai-nilai tersebut tercantum dalam pembukaan Undang-undang 1945 alinea ke IV yaitu, (1) Ketuhanan Yang Maha Esa; (2) Kemanusian yang adil dan beradab; (3) Persatuan Indonesia; (4) Kerakyatan yang dipimpin oleh hikmat kebijaksanaan dalam permusyawaratan dan perwakilan; dan (5) 
Keadilan sosial bagi seluruh rakyat Indonesia. Di dalam Pancasila ini terdapat nilai-nilai yang dapat membantu membangun karakter bangsa, Yalida (2019) menyatakan ada 11 (sebelas) penjabaran nilai Pancasila yang dapat membangun karakter bangsa yaitu, nilai religius, nilai kejujuran, nilai toleran, nilai disiplin, nilai mandiri, nilai demokratis, rasa ingin tahu, nilai semangat kebangsaan, nilai cinta damai, nilai peduli terhadap lingkungan, nilai peduli sosial.

\section{Tabel 2}

\section{Nilai-Nilai Penjabaran Pancasila Sebagai Pembangun Karakter Bangsa}

\begin{tabular}{|c|c|}
\hline Nilai Religius & $\begin{array}{l}\text { Nilai religius mengarahkan aspek spiritual yang dipahami sebagai cara } \\
\text { pandang tentang hakikat diri termasuk menghayati dan menghargai agama } \\
\text { yang dianut. sikap spiritual ini mencakup suka berdoa, senang } \\
\text { menjalankan ibadah, selalu bersyukur dan toleransi terhadap agama lain. } \\
\text { Dengan menanamkan nilai religius pada masyarakat Majasetra yang } \\
\text { sebagian besar beragama islam, tentunya paham mengenai nilai dan sikap } \\
\text { yang baik sudah sepatutnya dipahami dan dijalankan sesuai dengan ajaran } \\
\text { yang diajarkan. masyarakat harus pintar memilah dan memilih hal apa saja } \\
\text { yang dibawa arus globalisasi yang sesuai dengan nilai religius bangsa } \\
\text { Indonesia. }\end{array}$ \\
\hline Nilai Kejujuran & $\begin{array}{l}\text { Nilai kejujuran patut ditanamkan dalam karakter bangsa, masyarakat } \\
\text { Majasetra yang berkarakter jujur tentu dapat mempertanggungjawabkan } \\
\text { setiap hal yang menjadi keputusannya. }\end{array}$ \\
\hline Nilai Toleran & $\begin{array}{l}\text { Proses pembiasaan nilai toleransi merupakan keharusan yang penting } \\
\text { dikembangkan dalam membangun karakter bangsa. Bangsa Indonesia } \\
\text { yang memiliki keberagaman agama, suku, ras dan budaya menjadi } \\
\text { tantangan tersendiri dalam menghadapi perubahan. Untuk itu, nilai } \\
\text { toleransi perlu ditanamkan dalam karakter bangsa masyarakat Majasetra } \\
\text { agar terciptanya perdamaian dan persatuan. }\end{array}$ \\
\hline Nilai Disiplin & $\begin{array}{l}\text { Nilai disiplin merupakan nilai yang dikembangkan melalui tindakan } \\
\text { dengan patuh terhadap hukum dan norma yang ada. Pesatnya arus } \\
\text { globalisasi membawa pengaruh ideologi liberalisme, maka dari itu sikap } \\
\text { disiplin terhadap hukum dan norma yang ada di Indonesia perlu } \\
\text { ditanamkan, sehingga masyarakat Majasetra paham dan tunduk terhadap } \\
\text { hukum dan norma yang berlaku. }\end{array}$ \\
\hline Nilai Mandiri & $\begin{array}{l}\text { Nilai mandiri pada karakter bangsa akan menumbuhkan sikap tidak } \\
\text { ketergantungan. Bangsa yang berkarakter mandiri akan tumbuh dan tegak } \\
\text { berdiri dengan usaha dan tanggung jawab yang kuat dalam mewujudkan } \\
\text { Indonesia yang lebih baik. }\end{array}$ \\
\hline Nilai Demokratis & $\begin{array}{l}\text { Karakter yang demokratis akan selalu menempatkan pandangan bahwa } \\
\text { semua orang harus diperlakukan sama. Nilai demokratis akan membangun } \\
\text { karakter yang peduli akan eksistensi Pancasila dan mementingkan } \\
\text { kehidupan berbangsa dan bernegara dibanding kepentingan pribadi. }\end{array}$ \\
\hline Nilai Rasa Ingin Tahu & $\begin{array}{l}\text { Bangsa yang memiliki rasa ingin tahu yang tinggi tentu akan peduli } \\
\text { terhadap berbagai fenomena yang terjadi terhadap bangsanya. Tentunya, } \\
\text { hal ini akan menumbuhkan rasa kepedulian terhadap bangsa Indonesia. }\end{array}$ \\
\hline Nilai Semangat Kebangsaan & $\begin{array}{l}\text { Nilai semangat kebangsaan perlu ditanamkan dalam menghadapi } \\
\text { pengaruh negatif globalisasi, bangsa yang berkarakter semangat akan } \\
\text { menumbuhkan rasa mencintai tanah air dan dapat menghadapi arus } \\
\text { globalisasi dengan bijak. }\end{array}$ \\
\hline Nilai Cinta Damai & $\begin{array}{l}\text { Pengembangan nilai cinta damai, merupakan prioritas dalam Pendidikan } \\
\text { karakter. Banyaknya perpecahan yang terjadi di desa Majasetra } \\
\text { menunjukan bagaimana kehidupan rukun belum terwujud sepenuhnya. } \\
\text { Menanamkan cinta damai tentu dapat mempertahankan eksistensi }\end{array}$ \\
\hline
\end{tabular}




\begin{tabular}{|l|l|}
\hline & $\begin{array}{l}\text { Pancasila. sebagai negara dengan keberagaman yang berlimpah, mencintai } \\
\text { perdamaian menjadi kunci dalam menjaga persatuan dan kesatuan antar } \\
\text { masyarakat desa Majahtera. }\end{array}$ \\
\hline Nilai peduli lingkungan & $\begin{array}{l}\text { Pembangunan nilai peduli lingkungan akan membentuk karakter bangsa } \\
\text { yang dapat peduli kepada sesama manusia, nilai peduli lingkungan } \\
\text { menjadi nilai yang dapat menyadarkan betapa pentingnya melestarikan } \\
\text { budaya dan nilai yang ada pada Pancasila. }\end{array}$ \\
\hline Nilai peduli Sosial & $\begin{array}{l}\text { Menanamkan karakter peduli sosial akan menghindarkan masyarakat dari } \\
\text { sifat individualisme yang marak terjadi saat ini di desa Majasetra. } \\
\text { Pentingnya karakter ini akan menumbuhkan kesadaran masyarakat akan } \\
\text { sifat saling tolong menolong dan peduli terhadap sesama manusia. }\end{array}$ \\
\hline
\end{tabular}

Nilai-nilai tersebut terkandung dalam Pancasila, untuk itu Pancasila diharapkan di tengah arus globalisasi yang pesat ini tidak kehilangan esensinya. Masyarakat di Desa Majasetra juga diharapkan dapat memahami makna dan nilai serta mengaplikasikannya dalam kehidupan. Pancasila sebagai dasar negara yang merupakan karakter bangsa Indonesia sudah sepatutnya sebagai bangsa yang berideologikan Pancasila karakter yang ditanamkan pada jati diri bangsa dapat sesuai dengan apa yang ada pada Pancasila. Meskipun, arus globalisasi semakin pesat, masyarakat Majasetra dapat memilih dan memilah nilai-nilai apa saja yang dapat membawa perubahan dan dapat membangun bangsa. Akibat adanya globalisasi ini, jadikan Pancasila sebagai tiang hidup berbangsa dan bernegara, agar keutuhan dan kesatuan bangsa Indonesia tetap dapat dijaga dan dipertahankan, selain itu karakter yang tertanam menunjukan pada karakter warga negara yang baik. Dengan tertanamnya karakter yang baik, maka masyarakat dapat membangun bangsa ke arah kemajuan yang dapat membawa perubahan dalam berbagai bidang aspek kehidupan nantinya. Dengan adanya penelitian ini, diharapkan Sebagai bangsa yang berideologikan Pancasila hendaknya kita dapat menanamkan nilai-nilai Pancasila sebagai pembangun karakter dalam diri melihat arus globalisasi yang pesat dan dampak yang ditimbulkan pula dapat merusak karakter bangsa. Oleh sebab itu, sebagai bangsa Indonesia hendaknya kita dapat menanamkan nilai-nilai yang ada dalam Pancasila sebagai pembangun karakter diri dalam berkehidupan berbangsa dan bernegara. Dengan memahami dan mengimplementasikan nilai Pancasila maka, karakter yang di cerminkan merupakan karakter bangsa Indonesia seharusnya.

\section{KESIMPULAN}

Arus globalisasi yang pesat membawa banyak perubahan diberbagai aspek kehidupan salah satunya aspek sosial budaya. Penyimpangan-penyimpangan sosial yang terjadi di desa Majasetra seperti sikap individualis, kekerasan, kenakalan remaja, bahkan tindakan pembunuhan menjadi faktor karakter bangsa yang menyusut. Oleh karena itu, nilai-nilai dalam Pancasila perlu diimplementasikan dalam kehidupan. hal ini karena bangsa Indonesia merupakan negara yang berideologikan Pancasila, dimana Pancasila dijadikan masyarakat sebagai pandangan berbangsa dan bernegara. Karakter bangsa Indonesia seharusnya dapat tercermin sesuai dengan nilai-nilai pada Pancasila. Hal ini yang menyebabkan Pancasila dapat dijadikan sebagai pondasi dalam membangun karakter bangsa Indonesia. Nilai-nilai Pancasila itu antara lain nilai religius, nilai kejujuran, nilai toleran, nilai disiplin, nilai mandiri, nilai demokratis, rasa ingin tahu, nilai semangat kebangsaan, nilai cinta damai, nilai peduli terhadap lingkungan, nilai peduli sosial. Nilai-nilai tersebut dapat ditanamkan pada masyarakat desa Majasetra.

\section{UCAPAN TERIMA KASIH}

Alhamdulilah puji syukur kepada allah swt, karena kehendaknya penulis dapat menyelesaikan penelitian yang berjudul Membangun Karakter Generasi Muda Melalui Implementasi Nilai-Nilai Pancasila Di Tengah 
522 Membangun Karakter Generasi Muda Melalui Implementasi Nilai-Nilai Pancasila Di Tengah Arus Globalisasi - Rani Fitriani, Dinie Anggraeni Dewi

DOI: https://doi.org/10.31004/edukatif.v3i2.367

Arus Globalisasi, tak lupa penulis juga mengucapkan terimakasih kepada semua pihak yang telah berkontribusi, sehingga penelitian ini dapat berjalan dengan baik.

\section{DAFTAR PUSTAKA}

Ad, P. (2016). Pembudayaan Nilai-Nilai Pancasila Bagi Masyarakat Sebagai Modal Dasar Pertahanan Nasional NKRI. Jurnal Moral Kemasyarakatan, 1(1), 15-36.

Anggraini, D., Fathari, F., Anggara, J. W., \& Ardi Al Amin, M. D. (2020). Pengamalan Nilai-Nilai Pancasila Bagi Generasi Milenial. Jurnal Inovasi Ilmu Sosial Dan Politik, 2(1), 11. https://doi.org/10.33474/jisop.v2i1.4945

Asmaroini, A. P. (2016). Implementasi Nilai-Nilai Pancasila Bagi Siswa Di Era Globalisasi. Citizenship Jurnal Pancasila Dan Kewarganegaraan, 4(2), 440. https://doi.org/10.25273/citizenship.v4i2.1077

Damanhuri, D., Bahrudin, F. A., Legiani, W. H., \& Rahman, I. N. (2016). Implementasi Nilai-Nilai Pancasila Sebagai Upaya Pembangunan Karakter Bangsa. Untirta Civic Education Journal, 1(2), 185-198. https://doi.org/10.30870/ucej.v1i2.1890

Eva Imania Eliasa. (2008). Peran Bimbingan dan Konseling dalam Pendidikan Karakter Siswa. Universitas Negeri Yogyakarta, 1-12.

Gunawan, I. (2012). Pendidikan Karakter. 15/12/2015, 18 . http://fip.um.ac.id/wpcontent/uploads/2015/12/15.1_Pendidikan-Karakter.pdf

Kaelan. (2012). Problem Epistemologis Empat Pilar Berbangsa Dan Bernegara. Paradigma.

Kosim, M. (2011). Urgensi pendidikan karakter. Karsa, IXI(1), 85-92.

Lasiyo, Soeprapto, S., \& Wikandaru, R. (2019). Ruang Lingkup Pendidikan Pancasila. Universitas Terbuka, $1-43$.

Nurhaidah, M. I. M. (2015). Dampak Pengaruh Globalisasi Bagi Kehidupan Bangsa Indonesia. Pesona Dasar (Jurnal Pendidikan Dasar Dan Humaniora), 1(4), 1-14. https://doi.org/10.24815/pear.v7i2.14753

Pustaka, B. (2001). Kamus besar bahasa Indonesia. Jakarta: Balai Pustaka.

Rachmah, H. (2013). Nilai-Nilai Dalam Pendidikan Karakter Bangsa Yang Berdasarkan Pancasila dan UUD 1945. E-Jurnal Widya Non-Eksakta, 1.

Septian, D. (2020). Pemahaman Nilai-Nilai Pancasila Dalam Memperkuat Kerukunan Umat. TANJAK: Journal of Education and Teaching, 1(2), 155-168. https://doi.org/10.35961/tanjak.v1i2.147

Winarno. (2020). Paradigma Baru Pendidikan Kewarganegaraan. Bumi Aksara.

YALIDA, A. (2019). Pendiidikan Karakter Yang Berbasis Pada Nilai-Nilai Pancasiladi Kelas Iv Sdn No. 88 Kota Tengah Kota Gorontalo. Jurnal Pendidikan Islam Al-Ilmi, 88, 23-32. http://lonsuit.unismuhluwuk.ac.id/index.php/ilmi/article/view/262

Undang-Undang Dasar Negara Republik Indonesia Tahun 1945. 